\title{
Training, Organisational Commitment and Turnover Intention among Nigerian Civil Servants
}

\author{
Nwokeiwu Johnson ${ }^{1}$, Ziska Fields ${ }^{2}$, Nwali Anthony Chukwuma ${ }^{1}$ \\ ${ }^{1}$ Alex Ekwueme Federal University, Ndufu-Alike, Ikwo, Ebonyi State, Nigeria \\ 2University of KwaZulu-Natal, South Africa \\ jnwokeiwu@gmail.com, fields@ukzn.ac.za,nwali.anthony@funai.edu.ng
}

\begin{abstract}
This article reports on a study that focused on analysing the impact of training and development (T\&D) on organizational commitment and turnover intention among Nigerian public workers. The main objective of the study was to determine whether T\&D influences employees' commitment to the organization and the intention to stay or to leave the organization. Using a survey questionnaire and personal interview, data was collected from 297 civil servants and 8 departmental heads in Nigeria. Statistical analytical methods such as regression analysis were used to test the two hypotheses formulated, which were focused on determining the relationship between T\&D and turnover intention; as well as T\&D and the perceived impacts on employees' commitment. The result suggests a positive correlation between T\&D and organizational commitment and turnover intention. The result implies that investing in human capital is a critical strategic initiative for contemporary organizations because the ability of any organization to compete successfully is a function of the ability to retain their skilful and committed employees. The study contributes to knowledge in the field, as not much research has been done on the effects of T\&D on public servants in Nigeria. Most of the studies have been carried out in Europe, America, Asia and largely in the manufacturing and service sectors.
\end{abstract}

Keywords: Competence, development, learning, management, Nigeria

\section{Introduction}

Competing in the $21^{\text {st }}$ century requires that organizations identify and retain the best talent. The retention of employees is a significant factor in determining the returns to employers providing employee training and development (T\&D) and remains an integral part of the pursuit of improved growth and productivity (Panagiotakopoulos, 2011; Rabey, 2007). The need to invest in the current labour force is more urgent than ever before, as the ability to compete is dependent on knowledge development, how well that knowledge is managed and utilised and recognizing the unique competencies needed to survive in the $21^{\text {st }}$ century. Therefore, the goal of T\&D should be to enhance constant knowledge acquisition and innovation (Kumpikaite \& Čiarnienè, 2008) Organisations should create a situation where knowledge is shared in order to promote their strategic plan (Hatala \& Fleming, 2007). It has been widely acknowledged that training helps to develop employees' skills, enhance the quality of their work, improve productivity and build employee loyalty to an organization (Akinyele, 2007). Inadequate initial training, poor orientation to the job and lack of on-going training is considered among the major factors contributing to high staff turnover (Blenkner \& Rose, 2006). Well-trained employees are more competent and relish the opportunity to take control of their jobs.

These positive outcomes lead to more committed employees who are likely to remain in the organization (Brum, 2007; Owoyemi, Oyelere, Elegbede, \& Gbajumo-Sheriff, 2011). Reinforcement theory suggests that behaviour is controlled by its consequences (Jonck, 2001). An employee's decision to be more committed to the organization after training could stem from the experience of employees being promoted or rewarded for improving their performance after their training encounter. The empirical evidence has clearly demonstrated the importance of T\&D to employees' organizational commitment; therefore, there is a need for organizations to engage in T\&D as a means to enhance such commitment. There has been a dearth in the literature concerning the influence of T\&D interventions on organisational commitment, and turnover intentions among the civil servants in Nigeria. Therefore, there is a need for public organisations to engage in T\&D as a means of enhancing employees' psychological attachment to the organisational objectives. The current study provides an empirical assessment of the influence of T\&D interventions on organisational commitment and employees' turnover intentions at the Nigerian Railway Corporation. The next section provides a background of human capital development in Nigeria. The rationale is to improve operational efficiency in the ministries and raise public officials' standard of performance to the maximum level of proficiency. 
Background to the Study: Training in Nigeria has been considered an expense that is only justified when it is necessary, rather than an investment in the future and the success of government and businesses (Oluwatobi, \& Ogunrinola, 2011). Some organisations half-heartedly embrace T\&D, implementing it only on a very small scale when deemed necessary (Akanji \& Bankole, 2007). Furthermore, many employees view training sessions as an opportunity for free time to make extra money. Some employers send their employees for training with the wrong motive of claiming subsidies from the Industrial Training Fund (ITF) (Akanji \& Bankole, 2007). Others do so merely to fulfil the government's policy on T\&D. It has been shown that "when organizations view public policy as just a financing opportunity, they do not get any returns from training" (Dumas, Hanchane \& Royaume du Maroc, 2010, p. 585). There is an urgent need to cultivate multidimensional skills in the workforce (Ogundele, Hassan, \& Ibraheem, 2011) and to design programmes that accommodate the training needs of the public service in collaboration with public service departments (Balogun, 2011). The government embarked on T\&D in order to establish a civil service that is results-oriented.

\section{Literature Review}

Off-the-Job T\&D: There are key methods of training employees; these include off-the-job and on-the-job training methods. Off-the-job training is a type of training that takes place outside the actual work environment of an organization (Venkatesh, 2009). It is usually executed in a setting particularly chosen for it; an environment other than the normal work environment, which may or may not be near the actual work environment (Alipour, Salehi, \& Sahnavas, 2009). While on-the-job training develops best practices for a particular job, off-the-job training aims to improve basic competencies that are more general in nature (Agarwal, 2012). Off-the-job training is usually provided by professionals and academicians at a designated location. This technique includes lectures, seminars, workshops, simulation, programmed instruction, teleconferences, discussions and so forth. Off-the-job training offers participating employees the opportunity to meet new people in the same field, which gives them the opportunity to compare issues and discover new ideas. It concentrates on learning rather than performance (Chand, 2008) and conveys theoretical knowledge and behaviour (Kunasz, n.d.). It is suitable for training white-collar or managerial-level employees. The disadvantage of off-the-job training is that it has the potential to disrupt work activities (Awe, 2010). Moreover, it is more expensive than on-the-job training, as it requires an environment other than the workplace and experts are employed to conduct the training. However, off-the-job training allows trainees the opportunity to pay more attention to the material taught. Learning outside the work environment allows trainees to think and reflect, and broadens their skills more than on-the-job training. Trainees are able to ask questions and meet others in their field of work.

On-the-Job T\&D: On-the-job T\&D methods enable trainees to acquire knowledge and experience over a period while they perform their regular duties (Rothwell \& Kazans, 2004; Taiwo, 2007). This type of training targets mainly employees who do not possess the academic qualifications needed for their jobs. On-the-job training is highly effective, as it involves activities that enable employees to learn new roles and responsibilities (Forsyth, 2001). This provides them with the skills and knowledge to meet the demands of customers and other stakeholders (Pulley, 2006). Shadare, (2010) posits that, on-the-job training enables an employee to become accustomed to the instruments and materials that he/she will use in the workplace. This technique involves job directives given by an employee's manager or senior colleague who is talented and experienced (Adiele, 2009). Supervisors are presumed to know the modus operandi of good training and have the understanding and skills to produce a productive employee. It is most useful when employees are promoted and take up a new position, when productivity decreases, when there is a need for employees to specialise in a particular skill, or when there is a need to improve on the skills and knowledge to deal with the demands of the job (Alani \& Isola, 2009; Pettinger, 2002). On-the-job T\&D strengthens manager-subordinate relationships, has a positive motivational effect and above all improves performance (Forsyth, 2001). It offers managers the opportunity to take practical steps within a particular job context to attend to a specific need of the organisation prior to resorting to external methods, if necessary (Poro, 2009). However, on-the-job training is not without its limitations. Managers and experienced employees may be preoccupied with other managerial concerns and may not have time to train (Awe, 2010). Furthermore, the trainees may adapt the approaches advocated by the trainer, which may result in them adopting undesirable habits, with adverse consequences. Well-trained employees are more competent and relish the opportunity to take control of their jobs. 
Organisational Commitment: Organisational commitment has three parts: affective, continuance and normative commitment. Affective commitment is described as a passionate affection for, empathy with and participation in the achievement of organisational objectives (Ugboro, 2006). Affective commitment occurs in an organisation when employees' values are aligned with those of the organisation. In such a case, it becomes normal for the employees to be emotionally attached to the organisation (Ugboro, 2006). Continuance commitment, on the other hand, is described as employees' keenness to continuing working in an organisation because they have served it for many years; they stand to lose should they leave the organisation (Ugboro, 2006). Normative commitment can be described as a broad loyalty and feeling of duty to the organisation that results from an individual's belief that this is the moral and right thing to do. Employees believe that they ought to be committed to the organisation that provides them with their daily bread, even if this requires personal sacrifices (Ugboro, 2006).

These positive outcomes lead to more committed employees who are likely to remain in the organisation (Brum, 2007; Owoyemi et al., 2011). Reinforcement theory suggests that behaviour is controlled by its consequences (Jonck, 2001); an employee's decision to be more committed to the organisation after training could stem from the past experience of employees being promoted or rewarded for improving their performance after their training encounter. Further, employees who view T\&D as an incentive have a more binding commitment to achieving organisational goals and commit themselves to the organisation where they have career prospects (Brum, 2007; Klein, 2001; Silberman \& Philips, 2006; Smith, 2011). Young employees view T\&D as very important, because they want the opportunity to grow and advance their careers. They equally want to make a tangible contribution to the growth of the organisation for which they work. Shadare (2010, p.1214) ascertained that improving workers' competences enhances productivity as well as commitment and motivation. Highly committed employees are more likely to be motivated and involved in activities that achieve organisational objectives. This offsets many direct and indirect costs that an organisation may bear as a result of employees leaving (Brum, 2007; Kuvaas \& Dysvik, 2009; Newman et al., 2011).

The points made in the above paragraph support the social exchange theory, which posits that individuals are likely to support issues from which they stand to gain. Employees are happy to work for and identify with an organisation that is prepared to invest money in their career advancement (Shelton, 2001). Companies with highly committed employees can be $200 \%$ more productive than low-commitment companies (Flanagan, 2010). The same study found that $80 \%$ of employees who received T\&D felt strongly committed to their organisation. Bulut and Culha (2010) found that training positively affected employee commitment, while Sunyoung and Hea (2008) demonstrated that human resource development programmes such as on-the-job training, mentoring, coaching and self-development significantly influence organisational commitment. Abbas and Yagoob (2009) observed that a leadership development programme influences employees' attitude, commitment and trust in the organisation. Natarajan and Dinesh's (2011) study of 220 employees in India indicated that workers trained at a younger age who, stay longer in training show more commitment than other employees. The empirical evidence has clearly demonstrated the importance of T\&D to employees' organisational commitment; therefore, there is a need for organisations to engage in T\&D as a means to enhance such commitment. This study hypothesised as follows.

H10: There is no significant relationship between training/development and perceived organisational commitment.

H11: There is a significant relationship between training/development and perceived organisational commitk2ment.

Turnover Intention: Gone are the days when employees dedicated their entire working life to one organisation because of profound interest or a lack of better alternatives. T\&D has the potential to decrease staff turnover and turnover intentions in both the short and the long term and encourages the desire to contribute to the collective effort to achieve the overall goals of the organisation (Adenigi, 2010; Nickels, 2009). Every employee wants to remain in an organisation where he/she will be more competent and remain valuable and competitive (Nduchiadi, 2011; Young, 2007). T\&D lays a solid foundation for new employees and serves as a source of reinforcement for the old ones. Shelton (2001) notes that the rate of employee 
retention is higher in organisations that, are keen to train their staff members. Furthermore, it has been shown that employees who receive fewer training opportunities than they are entitled to contemplate leaving the organisation (Dysvik \& Kuvaas, 2008). This is due to the fact that T\&D helps an organisation to develop a culture where everyone feels valued and is prepared to work together for a common purpose. The results of the study by Pajo, Coetzer and Guenole (2010) suggest that employees who participate in T\&D are less likely to quit the organisation. However, the impact of T\&D on intention to quit is not straight-forward. In some instances, training has led to employees moving from one organisation to another. This is commonly experienced when the training is self-sponsored and/or when the skills acquired are of a more general nature.

Sieben (2005) suggests that specific training reduces employees' intention to look for another job, but also points out that self-sponsored training undertaken during employees' own time induces intention to leave. Furthermore, firm-financed training and firm-specific training minimise the rate of employees leaving the organisation (Hansson, 2008). This supports the standard human capital theory, which argues that investment in firm-specific skills reduces employee turnover, while investment in general skills could result in increased turnover or turnover intention (Flaherty, 2007). The transferability of general skills increases employees' mobility, because such skills are more attractive to other organisations, particularly those in the same sector (Nickels, 2009; Shelton, 2001). General training induces job mobility in the sense that the skills learnt can be useful to many organisations and can raise workers' productivity, and employability. On the other hand, specific skills bind the worker to the firm and serve as a barrier to exiting, as workers will lose a portion of the return on such skills if they move to another organisation (Jones, Jones, Latreille, \& Sloane, 2008). Contrary to human capital theory, Koster, De Grip and Fouarge (2009) suggest that investment in general training does not induce the intention to leave the organisation. The effect of general training on intention to quit may be reduced by the positive effect of job satisfaction experienced by employees after the training intervention based on the foregoing assumption that this study seeks to conduct an empirical analysis by hypothesising as follows.

H20: There is no significant relationship between training/development and perceived employees' turnover intention.

H21: There is a significant relationship between training/development and perceived employees' turnover intention.

Theoretical Background on Training and Development: Social exchange theory which was developed by Hormans (1958) posits that people enter into a relationship with the aim of making the best use of the benefits they will obtain (Cook \& Rice, 2003; Devan, 2006; Dysvik \& Kuvaas, 2008). The relationship between social exchange theory and T\&D and employees' performance can be explained in this manner. Employers provide training as an opportunity for employees to develop and be productive. Employees, on the other hand, endeavour to work hard on a given task and other related duties as a way of reciprocating the gesture from management, leading to improved performance (Dysvik \& Kuvaas, 2008). Therefore, a give-and-take formal obligation between employer and employees is moderated by the expectations of both parties in relation to the training offered by the employer. Providing training for employees may hence be regarded as a social exchange between the workers and management. This process starts when an organisation signals its readiness to accommodate its employees' interests by offering training opportunities.

Employees reciprocate by showing positive attitudinal and behavioural responses that assist the company in fulfilling its business objectives (Newman, Thanacoody, \& Hui, 2011). Numerous studies have shown that employees regard a T\&D opportunity as a sign that their organisation desires to enter into a social exchange with them (Newman et al., 2011). Equally important is Becker's classic study in 1993 (Marimuthu, Arokiasamy, \& Ismail, 2009), which explained how investment in a person's education and training is similar to a business investment in equipment. He also considers education and training to be the most important investment in human capital. He indicated that human capital emphasises the knowledge, expertise and skills of an individual accumulated through education and training. The fundamental assumption of this theory lies in the belief that education and training bring about increased learning. 
This enhances individual and organisational performance as well as business earnings (Marimuthu, Arokiasamy, \& Ismail 2009). Furthermore, according to Newman et al. (2011), individuals increase their organizational commitment if the organisation meets their expectations in relation to the fulfilment of their various individual needs. Employers want employees to be more productive and loyal, while employees, on the other hand, want a better career, job security and self-development (Bulut \& Culha, 2010). Social exchange theory does not directly demonstrate that T\&D will improve organizational performance per se. Rather, it suggests that T\&D can serve an incentive or motivating factor for employees to become more committed to the organization in exchange for future rewards. Therefore, more committed employees are more productive. Nonetheless, this theory does help to establish the link between T\&D and improved organizational performance. This assumption is further explained by the reinforcement theory developed by Skinner in 1957 and enhanced by Klapper in 1960, which posits that behaviour is controlled by its consequences (Ellis \& Johnson, 2014; Heath, 2007). That is to say, individuals will repeat behaviour that seems to produce good results or pleasant consequences, for instance a wage increase or promotion (Jonck, 2001).

Employees expect that attending T\&D programmes will enable them to acquire skills. They believe that these new skills will enable them to perform better in their jobs, which will lead to pleasant consequences such as an increase in salary. Those who believe in the above assumptions will put more effort into the T\&D itself. They will also be motivated to make better use of the knowledge and skills learnt during training, hence the increase in performance. Furthermore, output/productivity increases because the perceived interest shown in employees by offering them T\&D suggests that management has a special interest in their future career, which will motivate them to perform better as a way of reciprocating the favour. Based on the work done by the various researchers mentioned thus far, a conceptual framework was developed in Figure 1 in terms of the employees' training outcomes. The conceptual framework shows the links to the main objective of this article as it aims to determine whether T\&D influences employees' commitment to the organisation and the intention to stay or to leave the organisation.

Figure 1: Conceptual Framework for the Study (Formulated from the Researcher's Secondary Research)

\section{Conceptual Framework for Employees' Training Outcomes}

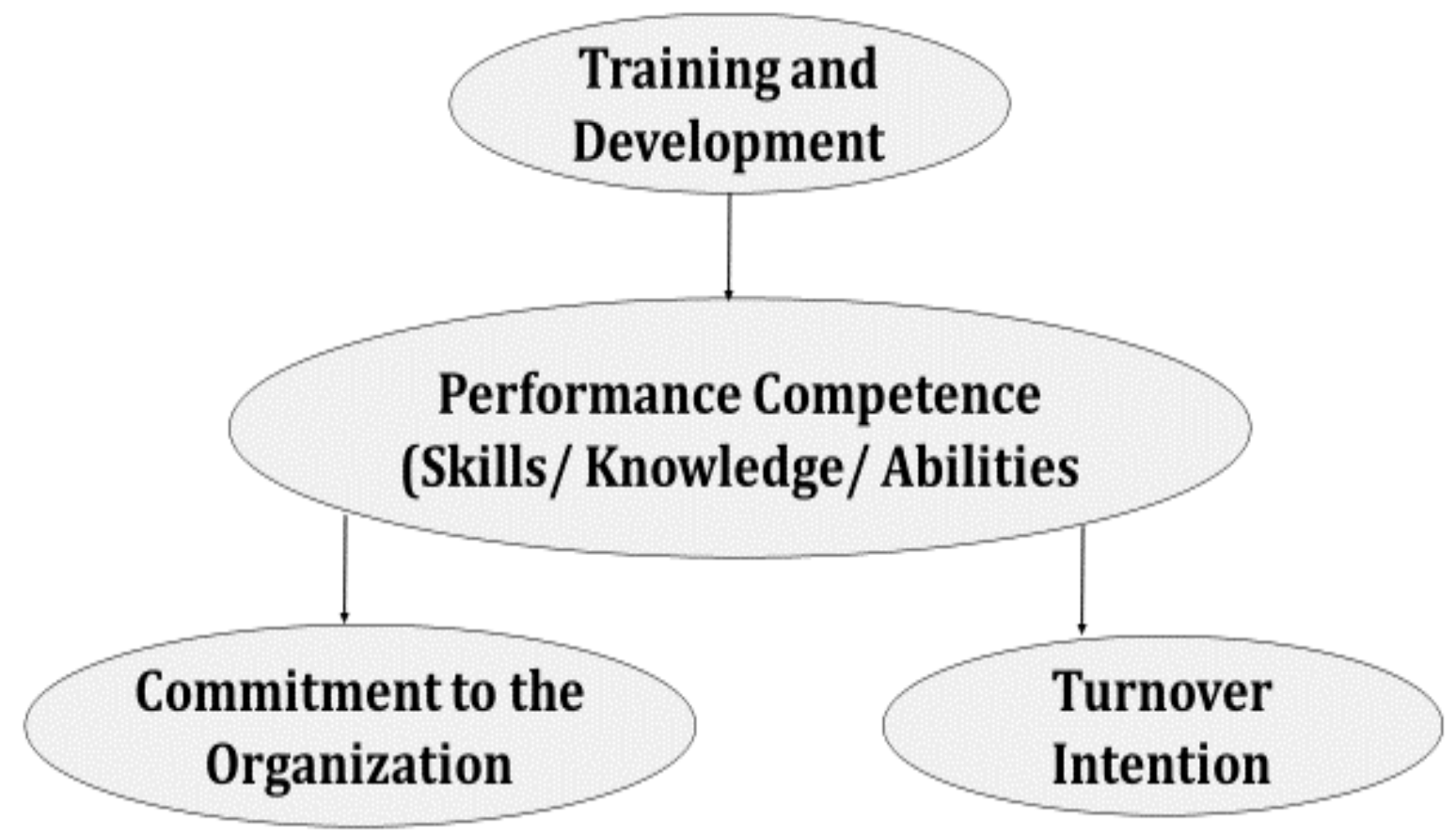


Performance Competence: The main purpose of any work-related training and development programme is to improve workers' levels of competencies, skills attitudes and work behaviours, as well as enhance employees' contributions to the overall corporate objectives (Indradevi, 2010). The proper training needs assessment by the Human Resources department is a necessity before embarking on T\&D program, otherwise the purpose of T\&D may be defected. Training needs assessment helps to identify skills deficiencies and those characteristics that are essential to improve the levels of employees' contribution. Specific training in the industry assists in ensuring flexibility, dynamic capabilities, and shapes employees behaviours based on the current and future needs of an organisation (Obisi, 2011). Nikandrou, Brinia, \& Bereri (2009, p. 262) found that workers are particular about their career growth and the need for new skills as reasons for engaging in learning activities. Santos and Stuart's (2003) put it that employees benefited from training through improved core competence, self-efficacy and organisational satisfaction. Costen and Salazar (2011) found that T\&D has a direct influence on employees' competence and impacts on their levels of productivity. Taiwo (2007, p. 18) on the other hand, found a significant relationship between a well-executed training programme and the acquisition of the skills required for employees to put up excellent performance on-the-job. More recently, Khan, Abbasi, Waseem, Ayaz and Ijaz (2016) reaffirmed that T\&D enhances employee morale, improves their skills and performance, and helps them excel in their jobs. Based on the importance of skills update, T\&D has become an integral part of HR functions in many organisations, as well as the public corporations. Judging from the literature, this study further hypothesised the following:

H30: Training/development and performance competence do not have a significant influence on organizational commitment.

H31: Training/development and performance competence have a significant influence on organizational commitment.

H40: Training/development and performance competence do not have a significant influence on employees' retention.

H41: Training/development and performance competence have a significant influence on employees' retention.

\section{Research Methodology}

This study adopted a pragmatic stance in the sense that it aimed to establish employees' perceptions using a questionnaire as well as interviews to collect data from the directors and the data were analysed both qualitatively and quantitatively. Inductive (qualitative) and deductive (quantitative) approaches were used for this study, as certain research questions can best be analysed qualitatively and others quantitatively. The target population for this study was the civil servants at a public corporation in Ebute Meta in Lagos State. The target population totalled 1, 328 civil servants. Sixty per cent of the employees were men and 35\% were women; and the majority of the participants were between the ages of 25 and 35 . Respondents were randomly selected. This study was a cross-sectional case study of civil servants in Lagos State. A crosssectional research method enables the researcher to gather facts once, at a particular point in time (Chen \& Hirschheim, 2004; Cohen, Manion, \& Morrison, 2010). The distribution and collection of the questionnaire took five months and the interviews took approximately a week.

Description of the Questionnaire: Five questions were developed to ascertain the impact of T\&D on NRC employees. Standardised questions with proven reliability were adapted to suit the present study, example, the Minnesota Satisfaction Questionnaire (MSQ, 1977). Sixteen items MSQ on organisational commitment were modified and used. These were set out to establish the rate of the employees' organisational commitment. Five questions were formulated to evaluate the impact of T\&D on employees' skills, knowledge and ability (performance competence). Five questions measuring employees' intention to stay or leave the organisation (turnover intention) after being exposed to a series of training and development programmes were also included in the research instrument. A pilot test was used to reveal any possible weakness or error in the design of a questionnaire and allows for any necessary modification (Cooper \& Schindler, 2008). 
This exercise determines whether the instrument will work and which questions need to be reviewed (De Vos, Strydom, Fouché, \& Delport, 2006). The information collected from the piloting phase enables the questionnaire to be improved before the proper study is carried out. The researchers assessed the results obtained from the present study and other test results that measured the same constructs. Both structured and semi-structured questions were used for the interviews; this allowed for in-depth insight into the nature of the management and outcomes of T\&D interventions. The data were obtained by conducting a face to face interview with eight directors of the NRC. The study benefited from seeking information from well-informed directors by tapping into their knowledge. According (Saunders, Lewis, \& Thornhill, 2009), questionnaires are more useful if used in conjunction with in-depth interviews to understand the facts under review. This study combined two data-collection methods, questionnaires and personal interviews. Semi-structured interviews were deemed appropriate, as they enabled the researcher to probe and explore the participants' ideas and perceptions of the main themes of the conceptual model. Open-ended questions were also used in most parts of the interview to inspire the interviewees to respond willingly to the questions. The qualitative data collected through the interviews was transcribed, and manually analysed using thematic content analysis. Creswell (2012) recommends that manual analysis of qualitative data may be preferred by the researcher when the database is less than 500 pages of transcripts; it allows for files to be tracked effortlessly and makes it easy to find test passages.

\section{Results and Discussion}

The quantitative data collected in this study was analysed using descriptive and inferential statistical tools. Descriptive and inferential statistics were used to transform the data into an easily understandable form and to enable generalisations to be drawn. The Statistical Package for Social Sciences (SPSS) Statistics (Version 24.0) was used for the quantitative data analysis. Descriptive statistics provide simple summaries of the immediate data and inferential statistics were used to draw conclusions. A p-value of $<0.05$ was considered statistically significant. The analysis started with the calculation of Cronbach's alpha to determine the reliability of the measuring instrument used for the study, which included training/development, organisational commitment, performance competence, and turnover intention. Questions with low values were eliminated and the Cronbach's values of most of the measuring instruments were above 0.7 , indicating a high degree of inter-correlation among the items and confirming that the items relate to a common construct. Each of the above-mentioned variables was measured by asking the participants to state their extent of agreement (on a Likert scale) with each of a number of statements.

The questionnaire contained a mix of positively and negatively worded items, which usually indicates that the negatively worded items need to be reversed in order to avoid very low and/or incorrect Cronbach's alpha values. Normally, all negatively worded items need to be reversed before a total score can be calculated for the scale; this guarantees that all items are scored in such a way that helps prevent bias (Pallant, 2011). Therefore, during coding, all statements that had strong negative correlation were reversed-scored in this study. Disagreement with the statement was therefore seen as a positive response. Consequently, the coding for the responses to these statements was changed so that a strongly disagree response had the highest coding (5) and a strongly agree response the lowest coding (1), while in the coding for the positive statements, a strongly disagree response had the lowest coding (1) and the strongly agree response the highest coding (5). Examples include: turnover intention - I often thought of quitting my employment in recent times; commitment - I actually do not feel that the organisation's problems are my problems; and commitment - I do not feel emotionally attached to my organisation.

The Cronbach's alpha calculation was carried out to determine the reliability of the measuring instruments used for this study. The employees' and the manager' responses were consistent with each other, which is an indication that the result is reliable. Cronbach's alphas for training/development, turnover intention and organisational commitment were obtained as presented in Table 1. A Cronbach's alpha value of 0.7 or higher indicates a high degree of inter-correlation among the items and confirms that the items relate to a common construct. The Cronbach's alphas for all the variables measured were above 0.7 and were therefore accepted as reliable measurements. The descriptive statistics illustrated in Table 1 shows the means, standard deviations and the reliabilities for all variables measured in this study. All the variables were measured on a five-point scale. All the scores for the variables ranged from a minimum of 1 to a maximum of 5. 
Table 1: Descriptive Statistics

\begin{tabular}{|c|c|c|c|c|c|c|}
\hline \multicolumn{7}{|l|}{ Descriptive Statistics } \\
\hline & $\mathrm{N}$ & Minimum & Maximum & Mean & Std. deviation & Alpha \\
\hline $\begin{array}{l}\text { Performance competence } \\
\text { (training) }\end{array}$ & 297 & 2.000 & 5.000 & 3.88 & 0.607 & 0.705 \\
\hline Turnover intention & 297 & 1.400 & 5.000 & 3.421 & 0.687 & 0.752 \\
\hline Organisational commitment & 297 & 2.300 & 4.583 & 3.494 & 0.455 & 0.710 \\
\hline Valid N (list-wise) & 297 & & & & & \\
\hline
\end{tabular}

Source: emerged from the statistical analysis

The mean average score of the variables measured ranges from 3.42 (turnover intention) to 3.88 (organisational commitment). The mean score of 3.42 for turnover intention means that the majority of the employees may not be contemplating leaving the organisation, while the mean score of 3.49 for organisational commitment also signifies that the majority of the employees felt more committed to the organisation after they received the training. The mean score of 3.88 signifies that most of the employees felt that the training they received impacted more on their competence and performance.

Training/Development and Organisational Commitment: The directors put it that the employees' psychological attachment to the organisation (NRC) were, reasonably high after the training and development programme. The non-numerical data displayed in Table 2, informs that training and development programmes improved the levels of employees' loyalty to the goal and aspirations of the organisation. M2 indicated that "employees' commitment is very high, so the training served as a source of motivation". M6 explained that "training and development initiatives help to build positive perception and feelings about the organization among the employees". In comparison, the employees' and the directors' responses were consistent with each other; which is an indication that the result is reliable. The uniformity of the results emanated from the numerical and non-numerical evidence of methodological triangulation in this study. Having established the perceived influence of training/development on an organisational commitment from the two sources, it is also necessary to examine the influence of training on employees' turnover intention.

Table 2: Directors' Responses

\begin{tabular}{lllll}
\hline Effectiveness of the Training Regarding Organisational Commitment \\
\hline Categories & $\begin{array}{l}\text { Definition } \\
\text { of Categories }\end{array}$ & $\begin{array}{l}\text { Percentage of } \\
\text { Participants }\end{array}$ & Examples \\
$\begin{array}{l}\text { Employees' } \\
\text { commitment }\end{array}$ & $\begin{array}{l}\text { T\&D effectively } \\
\text { improved } \\
\text { employees' } \\
\text { commitment. }\end{array}$ & $100 \%$ & $\begin{array}{l}\text { M2 - "Employees' commitment is very high, } \\
\text { the training serves as a source of } \\
\text { motivation. }\end{array}$ \\
& & $\begin{array}{l}\text { M6 - "Training and development initiative } \\
\text { helps to build positive perception and } \\
\text { feelings about the organisation among the } \\
\text { employees." }\end{array}$ \\
\hline
\end{tabular}

Source: Emerged from the non-numerical data

The Pearson correlation (see Table 3) produced a weak statistically significant positive association between performances competence and employees' commitment $(0.203, \mathrm{n}=297, \mathrm{p}<0.001)$. The result indicates that the more employees acquire new skills and knowledge, the more likely they are to be committed to the organization. Therefore, there is a significant relationship between perceived performance competencies gained during T\&D and the perceived impacts on employees' commitment. This is consistent with the findings of other studies in the field of T\&D (Brum, 2007; Klein, 2001; Owoyemi et al., 2011; Silberman \& Philips, 2006; Smith, 2011), which established that training increases employee commitment. Employees perceive the benefits they receive from T\&D as an indication of the organization's commitment to them; they repay the organization by exhibiting a higher level of commitment to it. Of interest is that employees in the technical department showed more commitment than the administrative staff (the mean score for technical 
staff of 164.34 was higher than the mean of the administrative employees of 136.27). This difference in commitment was attributed to the fact that more of the technical staff had their training abroad, while all the administrative staff's training took place in Nigeria. Therefore, the higher the level of organisational investment in employees' development, the more committed employees will in return be to the organization.

Table 3: Training and Commitment

\begin{tabular}{llll}
\hline Correlations & & & \\
\hline & & Performance & Employee \\
T\&D & Pearson correlation & 1 & $0.203^{* *}$ \\
& Sig. (2-tailed) & & 0.001 \\
Employee & $\mathrm{N}$ & 285 & 282 \\
commitment & Pearson correlation & $0.203^{* *}$ & 1 \\
& Sig. (2-tailed) & 0.001 & \\
\multirow{2}{*}{ Correlation is significant at the 0.01 level (2-tailed). } & 282 & 293 \\
\hline
\end{tabular}

Turnover Intention after Training: The result obtained from employees and their managers suggest that T\&D has the potential to effectively lower employees' intention to resign from the organisation. However, $25 \%$ of the managers felt that the rate of low intention to resign could be attributed to the high unemployment rate in the country, rather than to T\&D programmes alone. As evident in Table 4, the bivariate correlation coefficient suggests that there is a weak but significant positive relationship between training/development and perceived turnover intention $(\mathrm{r}=0.248, \mathrm{n}=297, \mathrm{p}<0.000)$. The result shows that the more employees are exposed to training/development, the more likely they stay with the organisation.

Table 4: T\&D and Employees' Turnover Intention

\begin{tabular}{llll}
\hline \multicolumn{2}{l}{ Correlations } & & \\
\hline Variables & & 1 & 2 \\
1 & Training/development & -- & $0.248^{* *}$ \\
2 & Turnover intention & $0.248^{* *}$ & -- \\
\hline
\end{tabular}

** Correlation is significant at the 0.001 level (2-tailed).

Source: emerged from the statistical analysis

The null hypothesis $\left(\mathrm{H} 2_{0}\right)$, which states that there is no significant positive relationship between training/development and perceived employees' turnover intention, was not supported. The result implies that training programmes undertaken by the civil servants made tremendously influence on their intentions to remain in the employment of the Nigerian Railway Corporation. The directors' perceptions concerning the influence of training/development on employees, intentions to quit their employment at a public corporation in Nigeria presented in Table 5.

Table 5: Turnover Intention (Directors' Responses)

\begin{tabular}{lll}
\hline Categories & $\begin{array}{l}\text { Definition } \\
\text { of Categories }\end{array}$ & Examples \\
\hline Intention & to & $\begin{array}{l}\text { Intention to leave is } \\
\text { very low after training. }\end{array}$ \\
leave & $\begin{array}{l}\text { Interactions with the managers or employees indicate that } \\
\text { none of them is thinking of leaving the organisation, although } \\
\text { you can never tell people's intention. It is difficult to read } \\
\text { people's minds. Training and development have a way [of] } \\
\text { making people feel they belong and that they are valued } \\
\text { encourage to stay with the organisation." }\end{array}$ \\
\hline
\end{tabular}


Few employees may be "My guess will be only very few may be thinking of leaving, thinking of leaving. there is a high rate of unemployment in the country."

Difficult to say

Employees' retention
Retain rate was very high.

"The answer is the same as employees' turnover, I suppose. It is hard to tell".

'Employees' retention in this establishment has been very high and this training and development initiatives have helped them in increasing it even further. We operate in a very competitive environment, the employees who are competent and who have the knowledge and capabilities to be effective and efficient were most welcomed in all companies, especially here, companies are trying to attract and retain this type of employees from competitors. These essential skills and capabilities are acquired through training".

The high retention was partly because of the high unemployment rate in Nigeria.

Low rate of turnover, with the exception of retirement

"Training and development and other factors like unemployment in the country have positively influenced our high employees' retention".

'We have very low employees' turnover in recent time, except for those who are retiring and few who were relieved of their duties because they were no longer adding value to the organisation"

"The turnover was more or less the same, because we never had a problem with employees' turnover in the past, except for those who were retired either voluntarily or otherwise".

Source: emerged from the non-numerical data.

As illustrated in Table 5, the result obtained from the directors suggests that T\&D has the potential to effectively lower employees' intention to quit the organisation. The interpersonal interactions with the managers or employees indicate that none of them is thinking of leaving the organisation. One of the directors affirms that it is extremely difficult to read people's minds. However, training and development have a way of making the employees' feel more important and valued through investment in their growth and development. It was also emphasised that the low rate of employees' turnover may be linked to the high rate of unemployment in Nigeria. Therefore, one cannot conclude that training/development is $100 \%$ responsible for the low rate of employees' turnover at the Nigerian Railway Corporation. This implies that other factors, which are beyond the scope of this study, might be responsible for the low rate of employee's turnover intentions. Furthermore, rather than relenting on training/development as an employee retention strategy in isolation, other work and non-work related factors should be concurrently considered and measured by organisational development practitioners. Furthermore, the results of the interviews show that T\&D has the potential to reduce employees' intention to leave the organisation. This demonstrates that employees who perceived an increase in their competence based on the T\&D programme offered to them are less likely to leave the organisation than those who do not receive training.

Again, this finding substantiated those of Nickels (2009) and Adeniji (2010), who claim that T\&D has the potential to decrease staff turnover and turnover intention in both the short and the long run. Shelton (2001) and Williams and Arnett (2008) found that training enabled organisations to attract and retain skilled workers. It has been found that employees who received fewer training opportunities than they were supposed to contemplate leaving the organisation (Dysvik \& Kuvaas, 2008). The above findings strongly suggest that T\&D programmes induce employees' commitment to the organisation. It therefore makes sense that employers who need to increase their employee retention rate should consider T\&D and performance competence as an essential initiative. However, a new finding of this study is that T\&D may have little effect on reducing employees' intention to leave their organisation; an indication that other incentives or innovative programmes need to be considered alongside T\&D to reduce employee attrition. 
T\&D, Performance Competence and Organisational Commitment: A multiple regression analysis run to establish the extent to which T\&D, and performance competence jointly serve as a predictor of perceived organisational commitment among the civil servants at a public corporation in Lagos, Nigeria. The result of the inferential statistics used in testing hypothesis three $\left(\mathrm{H} 3_{0}\right)$ is presented in Table 6.

Table 6: Regression Model 1

\begin{tabular}{llllllll}
\hline Variable & R & R square & $\begin{array}{l}\text { Adjusted } \\
\text { R square }\end{array}$ & F & Beta & T & P value \\
\hline Constant & $.444^{\mathrm{a}}$ & .197 & .192 & 36.173 & - & 8.775 & .000 \\
Training and development (T\&D) & & & & & .343 & 6.384 & .000 \\
Performance competence (PC) & & & & & .214 & 3.980 & .000 \\
\hline
\end{tabular}

Dependent variable: Organisational commitment. Predictors: Training and development, performance competence, Source: emerged from the statistical analysis

The regression model presented in Table 6, showed that employees' training/development and performance competence jointly predicted $19.2 \%$ (Adjusted $\mathrm{R}^{2}=.192, \mathrm{p}<.001$ ) of the variations in perceived organisational commitment among selected civil servants in Nigeria. Comparing the standardised beta $(\beta)$ values of the two predictors (T\&D, $\beta=.343, \mathrm{p}<.001 ; \mathrm{PC}, \beta=.214, \mathrm{p}<.001$ ) in the regression model 1 , it is evident that T\&D is a better predictor of organisational commitment. The results showed that T\&D opportunities that workers were exposed to explained most of the variations in perceived organisational commitment among selected civil servants in Lagos. The null hypothesis three (H30), which states that T\&D, and performance competence do not have a significant influence on organizational commitment was not supported based on results presented in Table 6. According to the result of the Cohen's effect size calculator $\left(\mathrm{f}^{2}=.245\right)$, one can infer that employees' T\&D and performance competence have a medium influence on organisational commitment at a public corporation in Nigeria.

The finding suggests that employees who claimed to have acquired competencies through T\&D are more likely to be committed to the organisation than those who claimed otherwise. This result is an indication that employees' commitment may be enhanced by giving them the opportunity to participate in regular T\&D exercises. The finding of this study corroborated those of Bulut and Culha (2010), who found that training positively impacted on employee commitment. The association between T\&D and employees' commitment is that better-trained employees are more competent and relish the opportunity to take control of their jobs; hence, they are more committed (Brum, 2007; Owoyemi et al., 2011). This supports the social exchange theory, which posits that individuals are likely to support issues from which they stand to gain. However, this study made the discovery that training on its own is unlikely to make a large contribution to enhancing employees' commitment. This result mirrors the position of Pajo et al. (2010) that an organisation can achieve higher levels of the employee retention rate by investing in T\&D and work-related competence interventions.

T\&D, Performance Competence and Turnover Intention: A multiple regression was instrumental in assessing the significant influence of T\&D, and performance competence on perceived turnover intention among the civil servants at a public corporation in Lagos, Nigeria. T\&D and performance competence were engaged in the analysis as the predictors of employees' turnover intention. The result of the statistical tool used in testing hypothesis four $\left(\mathrm{H} 4_{0}\right)$ is presented in Table 7.

Table 7: Regression Model 2

\begin{tabular}{llllllll}
\hline Variable & R & R square & $\begin{array}{l}\text { Adjusted } \\
\text { R square }\end{array}$ & F & Beta & T & P value \\
\hline Constant & $.369^{a}$ & .136 & .131 & 23.218 & - & 4.937 & .000 \\
Training and development (T\&D) & & & & & .250 & 4.483 & .000 \\
Performance competence (PC) & & & & & .220 & 3.947 & .000 \\
\hline
\end{tabular}

Dependent variable: Turnover Intention. Predictors: T\&D, performance competence

Source: emerged from the statistical analysis 
The regression model illustrated in Table 7, revealed that employees' T\&D and performance competence jointly explained $13.1 \%$ (Adjusted $\mathrm{R}^{2}=.131, \mathrm{p}<.001$ ) of the variance in perceived turnover intention among selected civil servants in Nigeria. Judging from the standardised beta $(\beta)$ values of the two predictors and their corresponding $\mathrm{p}$ values, T\&D $(\beta=.250, \mathrm{p}<.001)$ makes the largest unique contributions to the variance in perceived employees' turnover intentions. Performance competence $(\beta=.220, p<.001)$ on the other hand, also makes a significant contribution to the variance in employee's turnover intentions. Empirically, hypothesis $\mathrm{H} 40$ was not supported, due to the fact that T\&D and performance competence have a significant influence on perceived turnover intentions at a public corporation in Nigeria. In accordance with the Cohen's effect size calculator for multiple regression ( $\mathrm{f}^{2}=.157$ ), which implies that $\mathrm{T} \& \mathrm{D}$ and performance competence have a medium influence on perceived employees' turnover intention at a public corporation in Nigeria. The uniqueness of the current finding is that T\&D (compared to performance competence) is a better predictor of employees' retention in the Nigerian Railway Corporation.

\section{Conclusion and Recommendations}

Conclusion: The overall objective of this article was to examine the influence of T\&D programmes on organisational commitment, and turnover intention of civil servants at a public corporation in Nigeria. The T\&D programmes improve civil servants work-related competence, and psychological attachment to the organisation. The issue of high turnover intention after T\&D programme is not common among the civil servants in Nigeria. Based on the empirical findings, one can conclude that a well-implemented T\&D programme improves civil servants' competence, and retention of high calibre of staff in the organisation. The implication of this result is that the more T\&D civil servants receive, the more likely they are committed to the organisation. Therefore, the higher the level of organisational investment in civil servants' development, the more committed employees will in return be to the organisation. The T\&D initiative was found to have the potential to positively influence employees' turnover intention rates in the organisation. This is an indication that regular T\&D programmes can help the NRC to effectively reduce its employees' intention to quit the organisation. The T\&D programme was helpful in retaining almost the entire NRC workforce for the period under review. Although the high retention rate was partly attributed to the high unemployment rate in the country, which made it almost impossible for employees to move from one job to another, T\&D is still an effective strategic initiative for employee commitment and retention.

Recommendations: This article provided an assessment of the influence of T\&D programmes, and performance competence on organisational commitment and turnover intention. The managerial implications put forward to the management of public corporations were based on the empirical evidence emanated from the hypotheses tested. With a significant relationship between T\&D programme and organisational commitment, public corporations in Nigeria should intensify efforts in ensuring regular update of employees' skills to improve the level of performance competence and workers' loyalty. Workers should be selected for T\&D on the basis of gap identification and employee's potential for development, rather than on the basis of nepotism. When T\&D opportunities are based on nepotism, other employees may feel less committed to the organisation. Exposing civil servants to T\&D opportunities can be used as a strategy to reduce employee turnover intention through enhanced organisational commitment. This study recommends that civil servants commitment to the public corporations in Nigeria can be enhanced through a series of wellexecuted T\&D programmes and improved performance competence.

Limitation and Scope of the Study: This study was limited to the opinions of public servants at the Nigerian Railway Corporation (NRC) who had participated in any form of T\&D activities. The emphasis of the present study was on the influence T\&D on employees' turnover intentions and their commitment to the organisation. The findings and conclusion of the current study should be approached with caution, as the findings were based on the perception of the civil servants at NRC. The results cannot be used to generalise as the opinions of all civil servants in Nigeria as a whole. The generalisation is limited to the NRC, Ebute Meta (Lagos, Nigeria). The conclusion and recommendations put forward based on the findings of the current study would assist the organisational development practitioners in designing T\&D programme to enhance organisational commitment and retention of competent workforce in other public corporations in Nigeria. 


\section{References}

Abbas, Q. \& Yaqoob, S. (2009). Effect of leadership development on employee performance in Pakistan. Pakistan Economic and Social Review, 47(2), 269-292.

Adeniji, M. A. (2010). Training and its multiplier effect on productivity at the Olabisi Onabanjo University Library, Ago-Iwoye, Ogun State, Nigeria. Journal of Management and Development Studies, 1(1), 124143.

Adiele, N. (2009). Effective business training methods.

Agarwal, A. (2012). Difference between on the job and off the job training. Retrieved from http://www.projectguru.in/publications/difference-between-on-the-job-and-off-the-job-training/

Akanji, T. \& Bankole, R. A. (2007). International briefing 19: Training and development in Nigeria. International Journal of Training and Development, 11(3), 223-233.

Akinyele, T. S. (2007). The impact of the Nigeria training programme on employee performance. Research Journal of Business Management, 1(1), 11-19.

Alani, A. R. \& Isola, A. W. (2009). Human capital development in Nigeria. Institute of Organization and Management in Industry, 15(3), 58-71.

Alipour, M., Salehi, M. \& Shahnavaz, A. (2009). A study of on the job training effectiveness: Empirical evidence of Iran. International Journal of Business and Management, I4 (11), 63-68.

Awe, B. R. (2010). Effective business training methods. Retrieved from http://www.helium.com/items/1920333-effective-business-training-methods?page=2

Balogun, A. (2011). Evaluation: The first step in the training cycle. Journal of Economics and Behavioural Studies, 2(2), 50-56.

Becker, G. S. (1993). Nobel lecture: The economic way of looking at behaviour. Journal of Political Economy, 101(3), 385-409.

Blenkner, M. \& Rose, B. (2006). Tailored and on-going training can improve job satisfaction. Retrieved from http://www.benrose.org/inc/Research/BetterJobsBetterCareSummary.pdf

Brum, S. (2007). What impact does training have on employee commitment and employee turnover? Schmidt Labour Research Centre Seminar Research Series. Retrieved from http://www.uri.edu/research/lrc/research/papers/Brum-Commitment.pdf

Bulut, C. \& Culha, C. (2010). The effects of organizational training on organizational commitment. International Journal of Training and Development, 14(4), 309-322.

Chand, S. (2008). Training methods: On the job training and off the job training methods. Retrieved from http://www.yourarticlelibrary.com/employees/training-methods-on-job-training-and-off-the-job training-methods/5421/

Chen, W. \& Hirschheim, R. (2004). A paradigmatic and methodological examination of information systems research from 1991 to 2001. Information Systems Journal, 14, 197-237.

Cohen, L., Manion, L. \& Morrison, K. (2010). Surveys, longitudinal, cross-sectional and trend studies. In: Cohen L, Manion L, Morrison K, eds. Research Methods in Education, 7th Ed. Abingdon: Routledge, 261-4.

Cook, S. K. \& Rice, E. (2003). Social exchange theory. Retrieved from https://campus.fsu.edu/bbcswebdav/institution/academic/social_sciences/sociology.

Cooper, R. D. \& Schindler, S. P. (2008). Business research methods (10th ed.). Singapore: McGraw-Hill.

Costen, W. M. \& Salazar, J. (2011). The Impact of Training and Development on Employee Job Satisfaction, Loyalty, and Intent to Stay in the Lodging Industry. Journal of Human Resources in Hospitality \& Tourism, 10(3), 273-284,

Creswell, J. W. (2012). Educational research: Planning, conducting, and evaluating quantitative and qualitative research (4th ed.). Boston, MA: Pearson, 204-35.

Devan, J. (2006). Social exchange theory.

De Vos, A. S., Strydom, H., Fouché, C. B. \& Delport, C. S. L. (2006). Research at grass roots: For the social sciences and human service professions (3rd ed.). Pretoria: Van Schaik.

Dumas, A., Hanchane, S. \& Royaume du, M. (2010). How does job-training increase firm performance? The case of Morocco. International Journal of Manpower, 31(5), 585-602.

Dysvik, A. \& Kuvaas, B. (2008). The relationship between perceived training opportunities, work motivation and employee outcomes. International Journal of Training and Development, 12(3), 138-157.

Ellis, J. \& Johnson, C. (Eds.) (2014). Reinforcement theory. Retrieved from http://learning-theory-andpractice.wikispaces.com/Reinforcement+theory 
Flaherty, C. N. (2007). The effect of employer-provided general training on turnover: Examination of tuition reimbursement programs. Stanford Institute for Economic Policy Research. Retrieved from http://www-siepr.stanford.edu/papers/pdf/06-25.pdf

Flanagan, M. J. (2010). Measuring the effectiveness of L\&D. Retrieved from http://www.trainingjournal.com/feature/2010-12-01-measuring-the-effectiveness-of-ld/

Forsyth, P. (2001). Developing your staff. London: Kogan Page.

Hansson, B. (2008). Job-related training and benefits for individuals: A review of evidence and explanations. Organisation for Economic Co-operation and Development (OECD) education working paper no. 19. Retrieved from http://library.ukzn.ac.za/TopNav/ElectronicResources/databasesbysubject927.aspx

Hatala, J. P. \& Fleming, P. R. (2007). Making transfer climate visible: Utilizing social network analysis to facilitate the transfer of training. Human Resource Development Review, 6(1), 33-63.

Heath, L. R. (2007). Reinforcement theory.

Hormans, G. C. (1958). Social behavior as exchange. American Journal of Sociology, 63(6), 597-606.

Indradevi, R. (2010). Training for Most Capable Workforce. Advances in Management, 3(12), 49-54.

Joint Admission \& Matriculation Board. (2016). 2016 application statistics. Retrieved February 10, 2017, from http://www.jamb.gov.ng/Statistics.aspx

Jonck, K. (2001). An introduction to training management for the new millennium in South Africa (2nd ed.). Cape Town: Cape Technikon.

Jones, M. K., Jones, R. J., Latreille, P. L. \& Sloane, P. J. (2008). Training, job satisfaction and workplace performance in Britain: Evidence from Wers 2004. WELMERC, School of Business and Economics, Swansea University. Retrieved from http://ftp.iza.org/dp3677.pdf

Khan, A. A., Abbasi, S. O. B. H., Waseem, R. M., Ayaz, M. \& Ijaz, M. (2016). Impact of Training and Development of Employees on Employee Performance through Job Satisfaction: A Study of Telecom Sector of Pakistan. Business Management and Strategy, 7(1), 29-46.

Klein, J. H. (2001). Invited reaction: The relationship between training and organizational commitment - a study in the health care field. Human Resource Development Quarterly, 12(4), 353-361.

Koster, F., De Grip, A. \& Fouarge, D. (2009). Does perceived support in employee development affect personnel turnover?

Kumpikaitè, V. \& Čiarnienė, K. (2008). New training technologies and their use in training and development activities: Survey evidence from Lithuania. Journal of Business Economics and Management, 9(2), 155159.

Kunasz, M. (N.d.). Methods and techniques used in vocational training. Retrieved from http://www.wneiz.pl/nauka_wneiz/sip/sip4-2008/SiP-4-12.pdf

Kuvaas, B. \& Dysvik, A. (2009). Perceived investment in employee development, intrinsic motivation and work performance. Human Resource Management Journal, 19(3), 217-236.

Marimuthu, M., Arokiasamy, L. \& Ismail, M. (2009). Human capital development and its impact on firm performance: Evidence from developmental economics. The Journal of International Social Research, $2(8), 265-272$.

MSQ. (1977). Minnesota Satisfaction Questionnaire (MSQ). Retrieved February 11, 2017, from www.psych.umn.edu/psylabs/vpr/msqinf.htm

Natarajan, N. K. \& Nagar, D. (2011). Induction age, training duration \& job performance on organizational commitment \& job satisfaction. Indian Journal of Industrial Relations, 491-497.

Nduchiadi. (2011). Training and development: The secret to employee retention. Retrieved from http://hubpages.com/hub/TRAINING-AND-DEVELOPMENT

Newman, A., Thanacoody, R. \& Hui, W. (2011). The impact of employee perceptions of training on organizational commitment and turnover intentions: A study of multinationals in the Chinese service sector. The International Journal of Human Resource Management, 22(8), 1765-1787.

Nickels, D. (2009). The effects of training on employee performance. Retrieved from http://blogs.payscale.com/compensation/2009/09/effects-of-training-on-employeeperformance.html

Nikandrou, I., Brinia, V. \& Bereri, E. (2009). Trainee perceptions of training transfer: An empirical analysis. Journal of European Industrial Training, 33(3), 255-270.

Obisi, C. (2011). Employee training and development in Nigerian organisations: Some observations and agenda for research. Australian Journal of Business and Management Research, 1(9), 82-91. 
Ogundele, O. J. K., Hassan, A. R. \& Ibraheem, A. (2011). Projecting the possible impacts of the National Economic Empowerment and Development Strategy (NEEDS) on human development in Nigeria. International Journal of Economics and Finance, 3(4), 162-169.

Okotoni, O. \& Erero, J. (2005). Manpower training and development in the Nigerian public service. African Journal of Public Administration and Management, 16(1), 1-13.

Oluwatobi, S. O. \& Ogunrinola, O. I. (2011). Government expenditure on human capital development: Implications for economic growth in Nigeria. Journal of Sustainable Development, 4(3), 72-80.

Omodia, S. M. (2009). Manpower development in Nigeria: Conceptual and methodological perspectives. Journal of Social Sciences, 18(2), 113-117.

Owoyemi, O. A., Oyelere, M., Elegbede, T. \& Gbajumo-Sheriff, M. (2011). Enhancing employees' commitment to the organisation through training. International Journal of Business and Management, 6(7), 280-286.

Pajo, K., Coetzer, A. \& Guenole, N. (2010). Formal development opportunities and withdrawal behaviors by employees in small and medium-sized enterprises. Journal of Small Business Management, 48(3), 281301.

Pallant, J. (2011). A step by step guide to data analysis using the SPSS programme: Survival manual (4th ed.). Australia: Allen and Unwin.

Panagiotakopoulos, A. (2011). Workplace learning and its organizational benefits for small enterprises: Evidence from Greek industrial firms. The Learning Organization, 18(5), 350-360.

Pettinger, R. (2002). Mastering employees' development. New York, NY: Palgrave.

Poro, A. (2009). Effective business training methods. Retrieved from http://www.helium.com/items/1559200-training-method?page=3

Pulley, P. A. (2006). On-the-job-training: Easy to do if you have the right program. Retrieved from http://wed.siu.edu/Journal/VolIInum2/article3.htm

Rabey, G. (2007). Diagnose - then act. Some thoughts on training today. Industrial and Commercial Training Journal, 39(3), 164-169. Retrieved from www.citeulike.org/article/1248882

Rothwell, W. J. \& Kazans, H. C. (2004). Improving on-the-job training: How to establish and operate a comprehensive OJP programme (2nd ed.). San Francisco, CA: Pfeiffer.

Saunders, M., Lewis, P. \& Thornhill, A. (2009). Research methods for business students (5th ed.). England: Pearson Education Limited.

Shadare, A. O. (2010). Influence of workers' training programmes on conflict reduction in industrial organizations in Nigeria. African Journal of Business Management, 4(7), 1240-1246.

Shelton, K. (2001). The effects of employee development programs on job satisfaction and employee retention. Retrieved from http://www2.uwstout.edu/content/lib/thesis/2001/2001sheltonk.pdf

Sieben, I. (2005). Does training trigger turnover ... or not? The impact of formal training on young men's and women's job search behaviour. Research Centre for Education and the Labour Market. Retrieved from http://arno.unimaas.nl/show.cgi?fid=3827

Silberman, M. \& Philips, P. (2006). The 2006 ASTD training and performance sourcebook. Retrieved from https://www.td.org/Publications/Books/2006-ASTD-Training-and-Performance-Sourcebook

Smith, G. P. (2011). Training and development lead to higher productivity and retention. Retrieved from http://www.businessknowhow.com/manage/higherprod.htm

Sunyoung, P. \& Hea, J. Y. (2008). The impact of participation in HRD programs on employee job satisfaction and organizational commitment in South Korea. Retrieved from http://www.midwestacademy.org/Proceedings/2008/papers/Park,Yoon\&Jo_4.pdf

Taiwo, A. S. (2007). The impact of Nigerian training programmes on employees' performance. Research Journal of Business Management, 1(1), 11-19.

Ugboro, I. O. (2006). Organizational commitment, job redesign, employee empowerment and intent to quit among survivors of restructuring and downsizing. Institute of Behavioural and Applied Management.

Venkatesh, R. (2009). Training and development: What is the difference between training and development? Retrieved from http://ezinearticles.com/?Whats-The-Difference-Between-Training-andDevelopment?\&id=1038575.

Williams, R. \& Arnett, L. (2008). The ROI of Employee Training and Development: Why a Hearty Investment in Employee Training and Development is so important. (Online) Available from: http://www.workforce.com/tools/features/roi_employeetraining.pdf.

Young, C. (2007). Employee training and development encourages employee retention. Retrieved from http://www.maximizepossibility.com/employee_retention/2007/07/training-and-or.html. 